\title{
Corrosion Inhibitive Performance of the Waste Orange Peels (Citrus Sinensis) on A36 Mild Steel in 1M HCl
}

\author{
Ayoola Ayodeji ${ }^{1, *}$, Durodola Bamidele ${ }^{2}$, Fayomi Sunday $^{3,4}$, Agboola Oluranti $^{1}$, Alagbe Edith ${ }^{1}$, \\ Olagoke Oladokun ${ }^{1}$, Nnabuko Daniel ${ }^{1}$ \\ ${ }^{1}$ Chemical Engineering Department, Covenant University, KM 10, Idiroko road, Ota, Ogun State, \\ Nigeria \\ ${ }^{2}$ Chemistry Department, Covenant University, KM 10, Idiroko road, Ota, Ogun State, Nigeria \\ ${ }^{3}$ Chemical, Metallurgical and Materials Engineering Department, Tshwane University of Technology, \\ P.M.B. X680, Pretoria, South Africa. \\ ${ }^{4}$ Department of Mechanical and Biomedical Engineering, Bells University of Technology, P.M.B \\ 1015, Ota, Ogun State, Nigeria \\ *E-mail: ayodeji.ayoola@ covenantuniversity.edu.ng
}

Received: 12 April 2021 / Accepted: 2 September 2021 / Published: 6 December 2021

\begin{abstract}
This research work was carried out to investigate the corrosion inhibitive performance of the extract obtained from waste peels of orange (citrus sinensis) on A36 mild steel in $\mathrm{HCl}$ medium. A36 mild steel metal coupons were immersed in dilute hydrochloric acid solution (1M) containing different concentrations of the waste orange peels extract inhibitor $(0-4 \mathrm{~g} / \mathrm{L})$ at different temperatures of $32^{\circ} \mathrm{C}$ $\& 45^{\circ} \mathrm{C}$ (during gravimetric tests), as well as $27^{\circ} \mathrm{C} \& 50^{\circ} \mathrm{C}$ (during potentiodynamic tests). The gravimetric analysis performed revealed the highest inhibition efficiency of the extract to be $94.33 \%$ at concentration of $4 \mathrm{~g} / \mathrm{L}$ and temperature of $32^{\circ} \mathrm{C}$. Also, results from this analysis revealed a spontaneous (irreversible) and physisorption mode of adsorption of the inhibitor molecules as well as the fitness of the Langmuir adsorption isotherm for the adsorption process. The phytochemical analysis carried out revealed the presence of tannins, saponins, flavonoids, terpenoids and steriods in the inhibitor. The results of the potentiodynamic polarization analysis showed that the inhibitor retarded the anodic dissolution of mild steel more than the cathodic reaction which causes hydrogen evolution via the discharge of hydrogen ions.
\end{abstract}

Keywords: Corrosion; $\mathrm{HCl}$; Inhibitor; Mild steel; Waste orange peels.

\section{$\underline{\text { FULL TEXT }}$}

(C) 2022 The Authors. Published by ESG (www.electrochemsci.org). This article is an open access article distributed under the terms and conditions of the Creative Commons Attribution license (http://creativecommons.org/licenses/by/4.0/). 